\title{
PENANAMAN NILAI-NILAI AGAMA PADA ANAK USIA DINI DI R.A. DDI ADDARIYAH KOTA PALOPO
}

\author{
Internalization of Religious Values to Early Children at \\ R.A. DDI Addariyah Palopo City
}

\author{
Muhammad Ali Saputra \\ Balai Penelitian dan Pengembangan Agama Makassar \\ Jl. A.P.Pettarani No.72, Makassar \\ Email: dianpermana30@gmail.com
}

Naskah diterima tanggal 10 Juni 2014. Naskah direvisi tanggal 6 Agustus 2014. Naskah disetujui tanggal 11 Agustus 2014

\begin{abstract}
Abstrak
Penelitian ini bertujuan mengembangkan pemahaman tentang penanaman nilai-nilai agama pada anak-anak usia dini di Palopo, RA DDI Addariyah sebagai subjek. Pertanyaan penelitian adalah bagaimana lembaga pendidikan agama mendidik dan menanamkan nilai-nilai agama pada anak peserta didiknya dan faktor-faktor apakah yang berpotensi menjadi pendukung maupun penghambat. Hasil penelitian menunjukkan bahwa, dalam upaya menanamkan nilai-nilai agama pada anak peserta didik, RA DDI Addariyah Palopo memadukan kurikulum Kementerian Agama (Kemenag) maupun kurikulum Kementerian pendidikan Nasional (Kemendiknas) maupun beragam metode penanaman. Sebagai faktor pendukung, para guru memiliki motivasi yang tinggi kendatipun tidak diimbangi dengan pendapatan yang memadai dalam melakukan tugasnya. Sedangkan, minimnya fasilitas dan kurangnya pendanaan dapat menjadi faktor penghambatnya. Sebagai rekomendasi, Kemenag memberi perhatian dan bantuan untuk meningkatkan fasilitas bagi lembaga-lembaga pendidikan usia dini tersebut maupun memberi pelatihan secara reguler kepada para gurunya.
\end{abstract}

Kata kunci: nilai-nilai agama, penanaman, anak usia dini

\begin{abstract}
This research intens on developing understanding about religious value implant to Early Children Education at Palopo. Taking RA DDI Addariyah Palopo as its subject. The questions are how the religious educational department educated and implanted religious values to their children and what factors are considered to be potentially supporting or inhabiting its efforts. It is revealed that RA DDI Addariyah used mixed of both curriculum from ministry of religious and ministry of national education and there are many implant methods to their children. As the supporting factors, The Teachers have highly motivation although it is not balanced with their income being equal to their job. Whereas minimal facilities and lack of external funding sources is considered to be potentially one of barrier factors. As recommendation, ministry of religious gives attention and aid to improve facility to the Early Children Educational Institutions although it gives on regular basis training to the teachers.
\end{abstract}

Keywords: religious values, implant, early children

\section{PENDAHULUAN}

$\mathrm{P}$ endidikan merupakan faktor kunci yang memegang peranan terbesar dalam kemajuan suatu bangsa dan peradaban. Pendidikan tidak hanya sekadar membentuk kecerdasan suatu bangsa, tapi juga ikut membentuk watak dan karakter yang kuat dari bangsa tersebut.
Permasalahan yang dihadapi oleh bangsa Indonesia saat ini yang sifatnya kompleks dan multidimensi, utamanya dalam dimensi moral memiliki akar dari lemahnya karakter moral pendidikan bangsa sendiri. Pendidikan yang efektif harus dimulai sejak awal, sejak anak-anak generasi penerus bangsa masih belia. 
Usia dini merupakan masa penting dalam pembentukan kepribadian anak (Thalib, 2010: 67). Anak-anak usia dini berada pada tahapan perkembangan kognitif dan emosional yang kritis. Apa yang diperolehnya akan menentukan kemajuan tahapan perkembangannya di masa depan. Mereka memiliki sejumlah potensi yang dapat dikembangkan, namun kemajuan dari perkembangan potensi itu tergantung pada pembinaan yang dilakukan sejak dini. Anak-anak yang mendapatkan pembinaan yang intensif dan optimal sejak dini akan mampu mengembangkan potensinya dengan baik dan optimal di masa depan, demikian pula mereka yang kurang mendapatkan pembinaan sejak usia dini tentunya akan kurang mampu mengembangkan potensinya kelak (Yasmin dan Sanan, 2010: 3).

Olehnya itu, sangatlah tepat jika dikatakan bahwa pembinaan karakter bangsa sudah dilakukan sejak pembinaan karakter anak-anak pada usia dini utamanya melalui penanaman nilai-nilai agama. Pembinaan terhadap anak-anak uisa dini pra sekolah telah dilakukan oleh lembaga PAUD yang beragam. Namun, penanaman nilai-nilai agama tersebut hanya akan efektif apabila dilakukan dengan cara pembinaan dan metode yang tepat. Penelitian ini juga sejalan dengan arah kebijakan Kemenag 2010-2014 di bidang pendidikan yang antara lain adalah peningkatan akses dan kualitas pendidikan anak usia dini, yang holistik dan integratif untuk mendukung tumbuh kembang secara optimal sehingga memiliki kesiapan untuk memasuki jenjang pendidikan selanjutnya (KMA No.2 Tahun 2010). Untuk itu, dipandang perlu untuk melakukan penelitian mengenai proses penanaman nilai-nilai agama di lembaga PAUD.

Selanjutnya, yang menjadi pertanyaan dalam penelitian ini sebagai berikut: Apa dan bagaimana lembaga pendidikan agama yang menyelenggarakan program pendidikan keagamaan pada anak usia dini? Bagaimanakah penanaman nilai-nilai agama pada anak usia dini? Dan faktor-faktor apa sajakah yang menunjang atau menghambat penanaman nilai agama di lembaga PAUD itu?

Tujuan dari penelitian ini adalah mengungkap lembaga pendidikan agama yang menyelenggarakan program pendidikan keagamaan pada anak usia dini, mengungkap bagaimana penanaman nilai-nilai agama pada anak usia dini di lembaga PAUD tersebut, dan mengungkap faktor-faktor yang menjadi penunjang ataupun penghambat penanaman nilai-nilai agama di lembaga PAUD itu.
Sedangkan manfaat yang dapat dipetik dari penelitian ini adalah manfaat teoretik maupun manfaat praktis. Manfaat teoretiknya adalah memberikan pengetahuan tambahan mengenai proses penyelenggaraan pendidikan agama pada anak-anak usia dini, khususnya menyangkut penanaman nilai-nilai agama pada mereka. Sedangkan manfaat praktisnya adalah sebagai masukan bagi pihak pembuat kebijakan dalam hal ini Kementerian Agama dalam merumuskan suatu kebijakan mengenai pendidikan agama, khususnya pendidikan keagamaan bagi anak-anak usia dini maupun yang terkait dengan lembaga penyelenggaranya.

Yang menjadi batasan konsep dalm penelitian ini adalah:

1. Nilai-nilai agama disini adalah dalam Islam yang meliputi nilai-nilai aqidah, ibadah, dan akhlak.

2. Penanaman nilai-nilai agama adalah proses menanamkan nilai-nilai aqidah, ibadah, dan akhlak untuk dijadikan sebagai pedoman dalam bertingkah laku.

3. Anak usia dini adalah anak yang berusia antara 4-6 tahun.

4. Lembaga Pendidikan Penyelengga PAUD disini adalah yang sifatnya formal, seperti Raudhatul Athfal (RA), Taman Pendidikan al-Qur'an (TPQ/TPA) yang sederajat (apapun istilahnya).

5. Penanaman nilai-nilai agama pada anak usia dini dikaji melalui komponen kurikulum, metode pembelajaran, dan sistem evaluasi.

\section{Tinjauan Pustaka}

Pendidikan Anak Usia Dini (PAUD) telah dikukuhkan oleh UU No.23 Tahun 2000 tentang Sistem Pendidikan Nasional sebagai salah satu upaya pembinaan yang ditujukan untuk anak sejak lahir sampai dengan 6 tahun yang dilakukan melaui rangsangan pendidikan untuk membantu pertumbuhan dan perkembangan jasmani dan rohani agar anak memiliki kesiapan dalam memasuki jenjang pendidikan lebih lanjut. PAUD memegang peranan sangat penting dalam sejarah perkembangan anak selanjutnya karena merupakan pondasi bagi dasar kepribadian anak. Anak yang mendapatkan pembinaan yang tepat dan efektif sejak dini akan dapat meningkatkan kesehatan serta kesejahteraan fisik dan mental yang akan berdampak pada prestasi belajar, etos kerja, dan produktivitas 
sehingga mampu mandiri dan mengoptimalkan potensi diri (Mulyasa, 2012: 45).

Pendidikan anak usia dini memiliki karakteristik yang berbeda dengan pendidikan regular seperti sekolah. Pendidikan pada anak usia dini lebih ditekankan pada upaya untuk membangun dan mengembangkan karakter anak sesuai dengan potensi dan perkembangan anak yang bersangkutan. Dalam hal pendidikan agama untuk anak usia dini, maka pembelajarannya lebih ditekankan pada bagaimana menanamkan nilainilai agama pada diri anak dengan memanfaatkan karakteristik PAUD, yaitu belajar, bermain, dan bernyanyi.

Penanaman nilai-nilai agama sejak masa usia dini merupakan hal yang sangat krusial karena dapat membentuk perilaku maupun mental spiritual dan keagamaan anak di masa depannya. Nilai secara harfiah mencakup arti harga, banyak sedikitnya isi, serta sifat-sifat (hal-hal) yang penting atau berguna bagi kemanusiaan (Pusat Bahasa Depdiknas, 2008: 1004). Nilai merupakan suatu kualitas yang diyakini kebenarannya dan dijadikan pedoman seseorang untuk bertindak dalam situasi sosial tertentu dan dalam memandang sesuatu itu baik,benar, berharga. Nilai agama adalah konsep mengenai penghargaan tertinggi yang diberikan masyarakat kepada beberapa masalah pokok dalam kehidupan keagamaan yang bersifat suci dan menjadi pedoman bagi tingkah laku keagamaan warga masyarakat. Nilai agama itu dapat dikatakan bersumber dan dikembangkan dari agama (Depdikbud, 1989: 615). Dalam agama Islam, nilai agama mencakup tiga aspek, yaitu aqidah, ibadah, dan akhlak. Nilainilai aqidah mengajarkan Allah sebagai pencipta alam semesta, nilai-nilai ibadah mengajarkan agar setiap perbuatan manusia senantiasa dilandasi hati yang ihklas, dan nilai- nilai akhlak mengajarkan agar setiap manusia berperilaku sesuai norma atau adab yang benar atau baik (Hakim, 2012: 69). Penanaman nilai-nilai agama adalah suatu upaya untuk mengenalkan dan mengajarkan intisari ajaran agama kepada anak agar ia dapat mengetahui dan memehaminya yang kelak akan membiasakan dirinya untuk melaksanakan ajaran agama tersebut.

Penanaman nilai-nilai agama di lingkup PAUD dilakukan sesuai dengan metode pendidikan khas untuk anak-anak usia dini dengan memperhatikan prinsip-prinsip perkembangan anak-anak usia dini tersebut. Dalam PAUD, guru bukan berperan sebagai pengajar, tapi sebagai pendidik. Aspek yang disentuh dalam pendidikan adalah hati dan perasaan, dan yang dominan pada anak usia dini adalah hati dan perasaaan. Sedangkan dalam pengajaran, aspek yang disentuh adalah akal dan otak, dan ini relevan dengan orang dewasa.

Dalam upaya menanamkan nilai-nilai agama pada anak-anak usia dini, tiga aspek yang harus diperhatikan adalah usia, fisik, dan psikis anak. Rasa dan nilai-nilai keagamaan akan tumbuh dan berkembang seiring dengan pertumbuhan dan perkembangan fisik dan psikis anak. Perhatian anak terhadap nilai-nilai dan pemahaman agama akan muncul manakala mereka selalu melihat dan terlibat dalam upacara-upacara keagamaan, dekorasi dan keindahan rumah ibadah, rutinitas, ritual orang tua dan lingkungan sekitar ketika menjalankan ibadah (Azizah, 2009: 30).

Penanaman nilai-nilai agama pada anak usia dini dapat menggunakan beragam metode yang penggunaannya disesuaikan dengan kondisi sekolah dan kemampuan guru dalam mengimplentasikannya. Metode yang umum digunakan adalah (Murdiono, tt: 7-10):

1. bercerita. Dalam cerita dapat ditanamkan berbagai nilai moral. Ketika bercerita, guru juga dapat menggunakan alat peraga untuk mengatasi keterbatasan anak yang belum mampu berpikir secara abstrak, juga memanfaatkan kemampuan olah vokalnya untuk membuat cerita lebih hidup.

2. bernyanyi. Merupakan pendekatan pembelajaran secara nyata yang akan membuat anak senang dan gembira. Anak diarahkan pada situasi dan kondisi psikis untuk membangun jiwa yang bahagia, senang menikmati keindahan, mengungkapkan rasa lewat keindahan dan nada.

3. bersajak atau syair. Merupakan salah satu kegiatan yang akan menimbulkan rasa senang, gembira, dan bahagia pada diri anak. Lewat sajak anak dibawa ke dalam suasana indah, halus, dan menghargai arti seni maupun makna dan untaiannya.

4. karyawisata, bertujuan untuk mengembangkan aspek perkembangan anak sesuai kebutuhannya. Tujuan ini perlu dikembangkan sesuai dengan tema-tema aspek perkembangan anak. Tematema yang sesuai adalah binatang, pekerjaan, kehidupan kota dan desa, pesisir, dan pegunungan.

5. pembiasaan dalam berperilaku. Ini dapat dilihat 
pada kegiatan sebelum dan sesudah belajar, berdoa sebelum makan dan minum, mengucap salam kepada guru dan teman, berbaris sebelum masuk kelas, dan sebagainya.

6. bermain. Nilai moral yang dikandungnya antara lain mau mengalah, kerjasama, tolongmenolong, budaya antri, dan menghormati teman.

7. metode outbond. Merupakan kegiatan yang menyatukan anak dengan alam, sehingga ia tidak hanya memahami apa yang dituturkan oleh gurunya di dalam kelas, tapi dapat melihatnya secara langsung, sehingga ada sinkronisasi antara yang terjadi di kelas dan yang tampak di alam terbuka.

8. bermain peran. Dengan bermain peran anak akan memiliki kesadaran untuk merasakan menjadi orang yang ia perankan dalam permainan peran itu.

9. diskusi. Maksudnya adalah mendiskusikan suatu peristiwa yang isinya menyangkut mengapa suatu hal dilakukan, mengapa anak dikatakan baik, dan sebagainya.

10. keteladanan. Secara kodrat, manusia adalah makhluk peniru atau suka melakukan suatu hal yang sama yang dilihatnya. Apalgi anakanak akan mudah meniru sesuatu yang baru dikenalnya, baik perilaku maupun ucapan orang lain.

\section{METODE PENELITIAN}

Penelitian ini bersifat kualitatif, yaitu penelitian yang bermaksud untuk memahami fenomena tentang apa yang dialami oleh subjek penelitian, misalnya perilaku, persepsi, motivasi, tindakan, dan lain-lain secara holistik dan dengan cara deskripsi dalam bentuk kata-kata dan bahasa (Moleong, 2008: 7).

Yang menjadi lokasi dalam penelitian ini adalah Kota Palopo. Pemilihan R.A. DDI Addariyah dilakukan atas saran dari Kasi Mapenda Kantor Kemenag Kota Palopo setelah berdiskusi dengan beliau dengan pertimbangan sekolah tersebut merupakan Raudhatul Athfal yang paling besar (setidaknya dari sisi jumlah siswa dan guru) diantara 4 Raudhatul Athfal yang ada di Kota Palopo. Dalam penelitian ini ada dua, yaitu data primer dan data sekunder. Data primer dikumpulkan melalui pengamatan dan wawancara. Peneliti melakukan pengamatan terhadap kondisi fisik R.A. DDI Addariyah Palopo serta proses pembelajaran nilai- nilai agama di dalamnya yang melibatkan guru dan siswa. Peneliti juga melakukan wawancara dengan Kepala Sekolah beserta guru-guru yang terkait dengan kondisi sekolah serta proses pembelajaran di dalamnya. Sedangkan data sekunder diperoleh dengan melakukan kajian terhadap dokumendokumen terkait yang dapat diperoleh. Data-data yang diperoleh tersebut selanjutnya dianalisis dengan melakukan proses identifikasi, kategorisasi, dan selanjutnya direduksi untuk ditampilkan secara deskriptif dan terakhir dilakukan penarikan kesimpulan/verifikasi.

\section{PEMBAHASAN \\ Profil R.A. DDI Addariyah, Palopo}

R.A. DDI Addariyah Palopo merupakan salah satu lembaga pendidikan di Kota Palopo yang berkecimpung dalam pendidikan anak usia dini atau lebih dikenal dengan nama PAUD. Sekolah yang bernaung di bawah Yayasan DDI (Darud Da'wah wal-Irsyad) ini pertama kali menjejakkan sejarahnya di Kota Palopo pada tahun 1988. Pada tahun 1997, TK DDI Addariyah telah memiliki murid sebanyak 20 orang. Baru pada tahun 2003, nama TK diganti menjadi R.A hingga sekarang.

Dalam menjalankan kegiatan pendidikannya, R.A. DDI Addariyah Palopo berlandaskan pada visi dan misi yang telah digariskan oleh pihak sekolah untuk mencapai tujuan yang telah ditetapkan. Yang menjadi visinya adalah "Terwujudnya penyelenggaraan pendidikan Islam usia dini, berkualitas, unggul, berakhlak mulia dilandasi nilainilai ajaran Islam". Yang menjadi misi R.A. DDI Addariyah Palopo adalah:

1. Menanamkan nilai-nilai anak sejak dini

2. Membentuk anak menjadi pribadi yang kreatif, mandiri dan bertanggung jawab terhadap diri sendiri, orang tua, dan masyarakat.

3. Menumbuhkembangkan semua potensi/ kemampuan yang dimiliki anak didik agar lebih terampil dan dapat mengembangkan kecakapan hidup.

4. Menanamkan kepada anak agar berperilaku atau berakhlak mulia sesuai ajaran Islam.

5. Melaksanakan kerjasama dengan semua pihak terkait utamanya orang tua.

Adapun tujuan R.A DDI Addariyah Palopo adalah:

1. Meletakkan dasar dan menanamkan nilai-nilai agama Islam dalam jiwa anak sejak dini agar di kemudian hari menjadi manusia yang bertaqwa, 
berbudi luhur, dan cerdas.

2. Mengembangkan aktivitas motorik kasar dan halus dan kreativitas anak melalui berbagai kegiatan agar anak memiliki keterampilan, kemampuan, dan pengalaman yang bermanfaat bagi pertumbuhan pribadi dan pengembangan kehidupan di masa mendatang.

3. Menyiapkan anak untuk mengikuti pendidikan selanjutnya dengan kualitas yang baik secara intelektual dan agamis.

4. Menjadikan sekolah unggul dan berprestasi di tingkat yayasan, kecamatan, dan kota.

Dewasa ini, R.A. DDI Addariyah Palopo yang memiliki NISS (Nomor Izin Operasional) 10127373000L ini menempati sebuah aula di Gedung Kantor Urusan Agama (KUA) Palopo yang beralamat di Jl. A.Tadda, Kecamatan Wara Timur, Kota Palopo dengan status menumpang. Aula tersebut berada di dalam bangunan permanen yang memiliki luas 150 meter persegi yang berada di atas lahan seluas 300 meter persegi. Fasilitas fisik demikian jelas tidak memadai untuk menunjang kegiatan belajar karena tergolong sempit dan terbatas.

Fasilitas dalam kelas mencakup perangkat shalat, gambar tuntunan shalat ataupun bagan rukun iman dan Islam dan sejenisnya yang digunakan saat memberikan materi ajar yang terkait dengan keagamaan, maupun perangkat bantu lain yang digunakan dalam pembelajaran hitung maupun bahasa. Fasilitas-fasilitas demikian umumnya diadakan secara swadaya oleh pihak sekolah, meskipun dari sisi kualitas maupun kuantitas masih tergolong minim.

R.A DDI Addariyah Palopo ini dibina oleh 7 orang guru, semuanya wanita. Dari jumlah tersebut, ada yang berstatus Pegawai Negeri Sipil (PNS) dan ada juga yang bersatus sebagai guru honorer. Mereka yang berstatus sebagai PNS adalah kepala sekolah ditambah 3 orang guru, sedangkan 4 guru lainnya berstatus honorer. Untuk yang berstatus PNS, 2 orang berasal dari instansi Kemenag dan 2 orang lainnya berasal dari instansi Dinas Pendidikan setempat. Dari segi tingkat pendidikan, ada 5 orang yang telah berstatus Sarjana S1, 1 orang berstatus Sarjana Diploma (A.Md), dan 2 orang lulusan SMA. Dari 5 orang yang berstatus Sarjana S1, 2 orang berlatar belakang Sarjana Agama (S.Ag), 3 orang berlatar belakang Sarjana. Ada 3 orang guru yang berstatus PNS sudah mendapatkan sertifikasi guru dan 2 orang guru yang berstatus honorer telah mengikuti diklat sertifikasi. Di samping itu, para guru tersebut masih jarang mendapatkan pelatihan-pelatihan/workshop yang berhubungan dengan peningkatan kapabilitas dan kompetensi mereka sebagai guru PAUD.

Untuk saat ini, guru yang berstatus honorer, setiap bulannya menerima upah sebesar Rp.200.000,dari pihak yayasan dan Rp. 250.000,- dari Kemenag setempat. Jadi, total yang diterima adalah $\mathrm{Rp}$. 450.000,- per bulan. Namun, jumlah tersebut tidaklah bersifat tetap. Honor yang diterima oleh guru-guru honorer tersebut jumlahnya bergantung pada jumlah murid yang ada pada saat tersebut. Semakin besar jumlah murid, semakin besar pula honor yang diterima, dan semakin sedikit jumlah murid, semakin kecil pula honornya.

Saat ini, tercatat ada sekitar 100 orang siswa yang sedang dididik di sekolah PAUD ini. Para siswa tersebut terdiri dari 54 orang laki-laki dan 46 orang perempuan. Para siswa ini berada pada kisaran usia 5-6 tahun, hanya sekitar 10 persen dari mereka yang berlatar belakang PNS atau pegawai kantoran. Sisanya sekitar 90 persen berasal dari golongan ekonomi lemah, baik itu pedagang pasar, nelayan, maupun tukang ojek. Faktor ekonomi ini dapat pula dijadikan sebagai penjelasan mengapa jumlah anak yang menjadi siswa di sekolah ini turun naik setiap semesternya. Seorang anak yang menjadi siswa pada semester ganjil belum tentu akan lanjut ke semester genap, ataupun sebaliknya. Yang menjadi daya tarik bagi sejumlah warga setempat untuk menyekolahkan anaknya di R.A. DDI Addariyah ini adalah murahnya biaya pendidikan yang dikenakan jika dibandingkan dengan sejumlah lembaga-lembaga PAUD yang ada di kota Palopo. Untuk setiap anak hanya dikenakan biaya SPP sebesar Rp. 30.000,- per bulannya dan ini sudah termasuk satu kali biaya makan. Selain itu, sekolah ini tidak mewajibkan kepada setiap siswanya yang baru untuk membeli perlengkapan seragam yang baru. R.A. DDI Addariyah Palopo sudah dikenal oleh warga setempat sebagai suatu lembaga PAUD di kota Palopo yang berbiaya murah, sehingga setiap tahunnya dapat merekrut murid baru tanpa melakukan promosi di tempat-tempat publik. Kehadirannya tentu merupakan suatu angin segar bagi masyarakat yang berpendapatan ekonomi lemah yang ingin memberikan pendidikan bagi anak-anaknya di saat dunia pendidikan semakin komersial dan menjadi mahal.

Hingga kini, biaya operasional sekolah di R.A. DDI Addariyah secara umum ditalangi sendiri 
oleh pihak pengelola sekolah. Bantuan-bantuan finansial dari luar yang sebenarnya dibutuhkan belum menjangkau pihak sekolah. Terkecuali bantuan rutin ATK (Alat Tulis Kantor) dari Kantor Dinas Pendidikan setempat dan bantuan berupa alat-alat bermain outdoor dari Kantor Kemenag setempat. Meskipun masih menghadapi berbagai keterbatasan baik dalam hal fasilitas fisik maupun finansial, namun anak-anak asuhan R.A. DDI Addariyah Kota Palopo telah berhasil menyabet sejumlah prestasi dalam beberapa kompetisi antar PAUD di kota Palopo. Prestasi tersebut antara lain Juara I Lomba menghapal al-Qur'an, Juara I (objektif) lomba memasang kancing. Perlombaanperlombaan tersebut biasanya diadakan oleh IGTKI (Ikatan Guru Taman Kanak-Kanak Indonesia), Ikatan Guru Raudhatul Athfal, ataupun beberapa perusahaan yang beroperasi di Kota Palopo.

\section{Penanaman Nilai-Nilai Agama di R.A. DDI Addariyah Kota Palopo}

Pendidikan agama merupakan salah satu hal yang penting dan urgen dalam dunia pendidikan dewasa ini. Tujuan pendidikan bukanlah sekedar membekali para siswa dengan seperangkat pengetahuan-pengetahuan supaya menjadi lebih cerdas secara kognitif, tapi juga membentuk watak dan karakter siswa menjadi watak dan karakter yang mulia. Pendidikan yang mengedepankan aspek pengetahuan kognitif semata dan mengabaikan pengembangan watak dan spiritual hanya akan melahirkan generasi-generasi yang dapat meruntuhkan peradaban suatu bangsa. Pendidikan agama akan lebih efektif manakala telah diberikan sejak anak masih berusia dini. Oleh karena itu, pendidikan agama pada lembaga-lembaga PAUD merupakan salah satu aspek terpenting dalam proses pembelajaran di PAUD. Dikarenakan peserta didik pada satuan PAUD memiliki karakter yang unik baik dari segi perkembangan mental dan intelektual sejalan dengan perkembangan fisiknya, maka pendidikan agama pada PAUD utamanya ditekankan pada penanaman nilai-nilai/moralitas agama, bukan pada bentuk pengajaran. Penanaman nilai-nilai agama pada anak usia dini merupakan sebuah upaya untuk mengajarkan ajaran-ajaran pokok suatu agama yang diharapkan akan menjadi pedoman dalam bertingkah laku.

\section{Kurikulum R.A. DDI Addariyah}

Kurikulum, sebagai program pendidikan, berfungsi sebagai pedoman umum dalam penyelenggaraan sistem pendidikan. Kurikulum memuat garis-garis besar program kegiatan yang harus dilakukan setiap penyelenggara pendidikan, antara lain tujuan pendidikan sebagai sasaran yang harus diupayakan untuk dicapai atau direalisasikan , pokok-pokok materi, bentuk kegiatan dan kegiatan evaluasi. Kurikulum yang digunakan di R.A DDI Addariyah merupakan perpaduan dari kurikulum yang dikeluarkan oleh Kemenag dan Kemendikbud.. Struktur kurikulum pada PAUD merupakan pola dan susunan bidang pengembangan yang harus ditempuh anak didik dalam kegiatan pembelajaran . Bidang pengembangan tersebut lah yang menjadi program pembelajaran di R.A. DDI Addariyah Palopo. Bidang pengembangan ini terbagi menjadi dua kelompok:

1. Bidang pengembangan pembiasaan (pengembangan diri), yaitu kegiatan yang dilakukan secara terus menerus dan ada dalam kehudupan sehari-hari anak, sehingga menjadi kebiasaan yang baik. Pengembangan pembiasaan ini mencakup pengembangan moral dan nilai-nilai agama serta pengembangan sosial keagamaan dan kemandirian, pembentukan akhlakul karimah.

2. Bidang pengembangan kemampuan dasar, yaitu kegiatan yang disiapkan oleh guru untuk meningkatkan kemampuan dan kreativitas anak sesuai tahap perkembangannya. Bidang ini meliputi pengembangan bahasa, kognitif, fisik motorik, dan seni kreativitas. Seluruh kegiatan tersebut terintegrasi pada pengembangan agama Islam.

Pengembangan kemampuan dasar diprogramkan dalam perencanaan semester, perencanaan minggu dalam bentuk Rencana Kegiatan Mingguan (RKM) dan perencanaan harian dalam bentuk Rencana Kegiatan Harian (RKH) di R.A. DDI Addariyah.

Perencanaan semester merupakan program pembelajaran yang dipetakan berisi jaringan tema, bidang pengembangan, kompetensi dasar, hasil belajar, dan indikator yang ditata secara urut dan sistematis, alokasi waktu yang diperlukan untuk setiap jaringan tema, dan sebarannya ke dalam semester 1 dan 2 . Tema adalah wadah yang digunakan untuk konsep-konsep kepada anak didik dengan menyatukan isi program kegiatan menjadi satu kesatuan yang utuh. Di R.A. DDI Addariyah Palopo, tema yang digunakan untuk kelompok A dan B sama, tapi daftar tema untuk Semester 1 dan Semester 2 berbeda. Daftar tema tersebut beserta alokasi waktunya tersaji pada Tabel 1 . 
Tabel 1. Daftar Tema di R.A. DDI Addariyah Palopo Semester 1 \& 2

\begin{tabular}{|c|c|c|c|c|c|}
\hline \multicolumn{3}{|c|}{ SEMESTER I } & \multicolumn{3}{|c|}{ SEMESTER II } \\
\hline $\mathrm{NO}$ & TEMA & WAKTU & $\mathrm{NO}$ & TEMA & WAKTU \\
\hline 1 & Diri Sendiri & 3 Minggu & 1 & Rekreasi & 4 Minggu \\
\hline 2 & Lingkungan & 4 Minggu & 2 & Pekerjaan & 3 Minggu \\
\hline 3 & Kebutuhanku & 4 Minggu & 3 & Alat Komunikasi & 2 Minggu \\
\hline 4 & Binatang & 3 Minggu & 4 & Air, Udara, Api & 2 Minggu \\
\hline \multirow[t]{3}{*}{5} & Tanaman & 3 Minggu & 5 & Tanah Airku & 3 Minggu \\
\hline & Jumlah & 17 Minggu & 6 & Alam Semesta & 3 Minggu \\
\hline & & & & Jumlah & 17 Minggu \\
\hline
\end{tabular}

Perencanaan mingguan disusun dalam bentuk satuan kegiatan mingguan (SKM). SKM merupakan penjabaran dari perencanaan semester yang berisi kegiatan-kegiatan dalam rangka mencapai indikator yang telah direncanakan dalam satu minggu sesuai dengan keluasan pembahasan tema dan subtema. Perencanaan mingguan efektif dalam satu tahun pembelajaran (2 semester) adalah 34 pekan.

Perencanaan harian disusun dalam bentuk satuan kegiatan harian (SKH). SKH merupakan penjabaran dari satuan kegiatan mingguan (SKM).
SKH memuat kegiatan-kegiatan pembelajaran, baik yang dilaksanakan secara individual, kelompok, maupun klasikal dalam satu hari. SKH terdiri atas kegiatan awal, kegiatan inti, istirahat/makan, dan kegiatan akhir. Setiap hari anak didik mulai bermain dan belajar dari pukul 07.00 pagi sampai dengan pukul 10.00 pagi.

Untuk materi ajar yang berkaitan dengan penanaman nilai-nilai agama dan moral pada R.A DDI Addariyah Palopo yang bersumber dari Kurikulum Kementerian Pendidikan dan Kebudayaan adalah seperti pada Tabel 2 di bawah:

Tabel 2. Kurikulum Agama R.A. DDI Addariyah Palopo versi Kemendikbud

\begin{tabular}{ll}
\hline Tingkat Pencapaian Perkembangan & \multicolumn{1}{c}{ Indikator } \\
\hline 1. Mengenal agama yang dianut & Menyebutkan macam-macam agama di Indonesia \\
& Menyebutkan agama yang dianut \\
& Menyanyikan lagu-lagu keagamaan \\
& Bersyair yang bernafaskan agama \\
& Menyebutkan tempat-tempat ibadah \\
& Menyebutkan macam-macam Kitab Suci \\
& Menyebutkan Kitab Suci yang dianut \\
& Berdoa sebelum dan sesudah beribadah \\
& Melaksanakan ibadah sesuai aturannya \\
& Berbuat baik terhadap semua makhluk Tuhan \\
& Berbicara dengan sopan \\
& Menyapa teman dan orang lain \\
& Berpakaian rapi dan sopan \\
& Selalu mengucapkan terima kasih jika memperoleh sesuatu \\
& Menghormati guru, orang tua, dan orang yang lebih tua \\
& Mendengarkan dan memperhatikan teman bicara \\
& Mau memohon dan memberi maaf \\
& Senang bermain dengan teman \\
& Bersikap jujur \\
& Suka menolong \\
&
\end{tabular}




\begin{tabular}{ll}
\hline 4. Membedakan perilaku baik dan buruk & Menyebutkan mana yang benar dan mana yang salah pada suatu persoalan \\
& Menunjukkan perbuatan yang benar dan salah \\
& Menunjukkan perbuatan yang baik dan buruk \\
& Melakukan perbuatan yang baik saat bermain \\
& Memelihara kebersihan lingkungan \\
& Berperilaku hidup hemat: air, listrik dan peralatan sendiri \\
& Menyebutkan hari-hari besar keagamaan \\
5. Mengenal ritual dan hari besar agama & Terlibat dalam acara keagamaan \\
& Menghormati teman yang sedang melakukan ibadahnya \\
6. Menghormati agama orang lain & Dapat hidup berdampingan dengan teman dari agama lain \\
& Menghormati perayaan hari besar agama lain \\
\hline
\end{tabular}

Adapun materi-materi ajar yang kelompok, yaitu Kompetensi Dasar Agama Islam berhubungan dengan agama Islam diambil dari dan Kompetensi Dasar Akhlak Perilaku/Sosial kurikulum yang dikeluarkan oleh Kementerian Emosional. Cakupan materi Kompetensi Dasar Agama. Materi tersebut dibagi menjadi dua Agama Islam tersaji pada Tabel 5 berikut:

Tabel 3. Kompetensi Dasar Islam dalam Kurikulum R.A. DDI Addariyah versi Kemenag.

\begin{tabular}{|c|c|c|}
\hline \multirow{2}{*}{$\begin{array}{c}\text { No } \\
1\end{array}$} & \multicolumn{2}{|c|}{ Kompetensi Dasar Agama Islam } \\
\hline & Hapalan doa sehari-hari: & Doa keluar dan masuk masjid \\
\hline & & Membaca basmalah sebelum beraktivitas \\
\hline & & Membaca Alhamdulillah setelah beraktivitas \\
\hline & & Doa sebelum dan sesudah belajar \\
\hline & & Doa sebelum dan sesudah tidur \\
\hline & & Doa untuk ayah dan ibu \\
\hline & & Doa kebaikan dunia dan akhirat \\
\hline & & Doa keluar dan masuk kamar mandi \\
\hline & & Doa Keluar dan masuk rumah \\
\hline & & Doa naik kendaraan \\
\hline & & Doa berpakaian \\
\hline & & Doa bercermin \\
\hline & & Doa sesudah azan \\
\hline & & Doa berbuka puasa \\
\hline 2. & Mengucapkan Kalimah Thayyibah & \\
\hline 3. & Melafazhkan adzan dan iqamah & \\
\hline 4. & Mengenal beberapa Asmaul Husna & \\
\hline 5. & Mengenal huruf hijaiyah & \\
\hline 6. & Iqra’/qira’ati & \\
\hline 7. & Hafalan surah al-Qur'an: & $\begin{array}{l}\text { S. Al-Fatihah } \\
\text { S. Al-Ikhlash } \\
\text { S. al-Falaq } \\
\text { S. an-Naas } \\
\text { S.al-Lahab } \\
\text { S. al-Kafirun } \\
\text { S. al-Ma’un } \\
\text { S. al-Ashr }\end{array}$ \\
\hline 8. & Dapat menceritakan beberapa ciptaan Allah SWT dan sifat-sifatnya & \\
\hline 9. & Menyebutkan nama malaikat dan tugas-tugasnya & \\
\hline
\end{tabular}




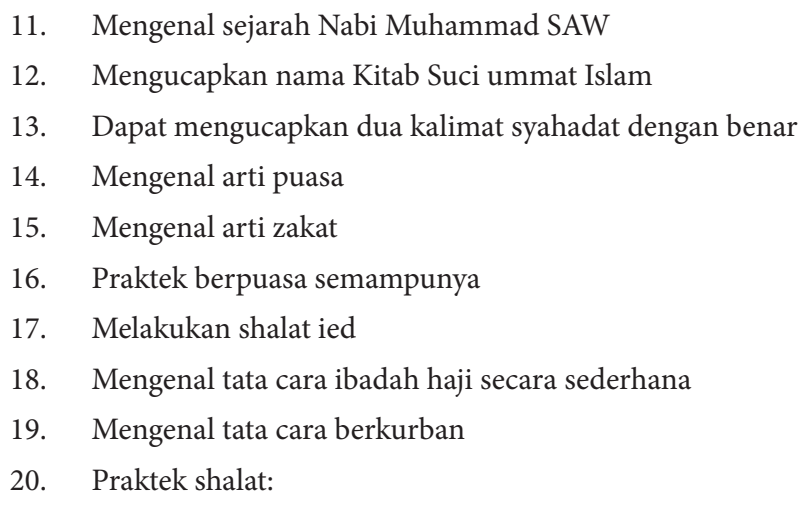

Wudhu/tayammum

Gerakan shalat

Bacaan shalat
Sedangkan cakupan materi Kompetensi Akhlak Perilaku/Sosial Emosional adalah seperti pada Tabel 4 berikut:

Tabel 4. Kompetensi Akhlak Perilaku/Sosial Emosional dalam Kurikulum R.A. DDI Addariyah Palopo versi Kemenag

\begin{tabular}{cl}
\hline No. & \multicolumn{1}{c}{ Kompetensi Akhlak Perilaku/ Sosial Emosional } \\
\hline 1. & Terbiasa mengucapkan salam \\
2. & Terbiasa menjawab salam \\
3. & Terbiasa membaca doa sebelum memulai kegiatan \\
4. & Senang berlatih khusyu' dalam berdoa dalam situasi \\
& yang sesuai \\
5. & Senang bersikap jujur \\
6. & Senang berlatih hormat kepada orang tua dan guru \\
7. & Rapi dalam bertindak, berpakaian, dan bekerja \\
8. & Berani karena benar dan mempunyai rasa ingin tahu \\
9. & Bang besar \\
10. & Tanggung jawab atas tugas yang diberikan \\
11. & Mau menerima tugas dengan ikhlas \\
12. & Mudah meminta maaf dan suka memberi maaf \\
13. & Senang menjadi pemimpin dan mau memimpin \\
14. & Tolong menolong dan dapat kerjasama \\
15. & Mampu mengendalikan emosi negatif \\
16. & Terbiasa mengikuti tata tertib dan aturan sekolah \\
17. & Berlatih mandiri \\
18. & Dapat membedakan milik sendiri dan sekolah \\
19. & Terbiasa mengucapkan terima kasih, tolong, dan \\
20. & Terbiasa mengembalikan mainan ke tempatnya \\
21. & Terbiasa berhenti bermain pada waktunya \\
22. & Terbiasa melafazkan adzan dan iqamah \\
23. & Terbiasa menjawab azan \\
\hline
\end{tabular}

24. Mengenal tata cara berakhlak terhadap alam dan binatang

25. Terbiasa mengambil makanan secukupnya

26. Tepat waktu saat berangkat sekolah

Jika mencermati aitem-aitem dalam kurikulum yang digunakan di R.A. DDI Addariyah Palopo, maka secara garis besarnya materi-materi yang terkait dengan nilai-nilai keagamaan yang dikembangkan di sana mencakup tiga hal: aqidah/ keimanan, ibadah, dan akhlak. Ketiga hal tersebut merupakan intisari dari nilai-nilai ajaran-ajaran Islam. Nilai-nilai aqidah mengajarkan manusia untuk percaya akan adanya Allah Yang Maha Esa dan Maha Kuasa sebagai Sang Pencipta alam semesta, yang akan senantiasa mengawasi dan memperhitungkan segala perbuatan manusia di dunia. Dengan merasa sepenuh hati bahwa Allah itu ada dan Maha Kuasa, maka manusia akan lebih taat untuk menjalankan segala sesuatu yang telah diperintahkan oleh Allah dan takut untuk berbuat dhalim atau kerusakan di muka bumi ini. Nilainilai ibadah mengajarkan pada manusia agar dalam setiap perbuatannya senantiasa dilandasi hati yang ikhlas guna mencapai rido Allah. Pengamalan konsep nilai-nilai ibadah akan melahirkan manusiamanusia yang adil, jujur, dan suka membantu sesamanya. Selanjutnya yang terakhir nilai-nilai akhlak mengajarkan kepada manusia untuk bersikap dan berperilaku yang baik sesuai norma atau adab yang benar dan baik, sehingga akan membawa pada kehidupan manusia yang tenteram, damai, harmonis, dan seimbang (Muhtadi, 2005:th).

Untuk memudahkan proses pembelajaran di R.A. DDI Addariyah Palopo, maka para siswa dibagi ke dalam dua kelompok, yaitu Kelompok A dan 
Kelompok B. Kelompok B merupakan kelompok anak yang memiliki tingkat kematangan yang lebih tinggi dari kelompok A. Pengelompokan ini didasarkan atas tingkat kematangan siswa, bukan atas tingkat usia dan dilaksanakan setiap akhir Semester 1 dan akhir Tahun Ajaran. Penentuan pengelompokan atas dasar tingkat kematangan ini mengacu pada Kriteria Ketuntasan Minimal. Saat ini di R.A. DDI Addariyah Palopo hanya ada satu kelompok, yaitu Kelompok B yang dibagi ke dalam 4 kelas.

Adapun model pembelajaran yang dikembangkan di R.A. DDI Addariyah Palopo adalah model pembelajaran berdasarkan area. Model ini lebih memberi kesempatan kepada anak didik untuk memilih kegiatan sendiri sesuai dengan minatnya. Pembelajarannya dirancang untuk memenuhi kebutuhan-kebutuhan spesifik anak dan menghormati keberagaman budaya. Kecuali itu juga menekankan pada pengalaman belajar bagi setiap anak, pilihan-pilihan kegiatan dan pusatpusat kegiatan serta peran serta keluarga dalam proses pembelajaran (http://ipisumedang.blogspot. com/2012/01/model-model-pembelajaran-paud-2. html). Ada empat area yang dikembangkan di sekolah ini, yaitu area agama, area bahasa, area matematika, area balok, dan area musik. Pada area agama, terdapat sejumlah alat bantu belajar di dinding, seperti tulisan Muhammad, Bismillah, Allah, maupun gambar tentang cara berwudhu dan shalat.

\section{Metode Penanaman Nilai-Nilai Agama di R.A. DDI Addariyah Palopo}

Untuk menanamkan nilai-nilai agama Islam pada anak-anak yang menjadi peserta didik pada R.A. DDI Addariyah Palopo, para guru di sana menggunakan sejumlah metode yang biasa digunakan dalam proses pendidikan di sekolahsekolah PAUD. Metode-metode tersebut adalah:

\section{Metode pembiasaan \\ Inti dari metode ini adalah pengalaman yang dilakukan secara berulang-ulang. Metode ini sudah terlihat dari kurikulum yang digunakan di R.A. DDI Addariyah. Banyak muatan-muatannya yang terkait dengan pembiasaan perilaku yang baik. Contohnya adalah siswa dibiasakan untuk mengucap salam, membaca doa sebelum melakukan kegiatan, ataupun dibiasakan untuk memanggil ibu guru dengan sebutan "Bunda". Agar pembiasaan ini}

menjadi efektif, perlu dilakukan secara konsisten dan jika perlu dibantu dengan reward.

\section{Metode peneladanan}

Metode ini mengharuskan guru untuk melakukan sendiri perilaku untuk dicontoh oleh anak-anak yang menjadi peserta didiknya. Metode ini sangat tepat digunakan utamanya untuk menanamkan nilai-nilai agama seperti halnya metode pembiasaan. Guru-guru di R.A. DDI Addariyah Palopo biasa mencontohkan perilaku yang hendak ditanamkan pada anak didiknya dengan melakukan sendiri perilaku tersebut, semisal berdoa, membalas salam, dan semacamnya. Secara psikologis, anak-anak yang berada pada kelompok usia dini cenderung suka mengamati suatu perilaku dan mudah menirunya.

\section{Metode demonstrasi}

Metode demonstrasi dilakukan dengan memperagakan atau mempertunjukkan apa/ perilaku yang hendak diajarkan/ditanamkan pada anak didik di depan mereka sendiri. Selain bermanfaat memberikan ilustrasi dalam menjelaskan suatu informasi, metode ini juga dapat membantu meningkatkan daya pikir mereka dalam mengenali mengingat, dan berpikir evaluatif. Contohnya adalah saat guru di R.A DDI Addariyah mengajarkan tata cara wudhu dan shalat dengan meminta salah seorang anak didiknya untuk mempraktekkannya di hadapan teman-temannya di bawah bimbingannya. Apabila ada yang keliru, maka akan dikoreksi oleh sang guru dengan memberi penjelasan-penjelasan sehingga peserta didik tidak akan salah mengambil kesimpulan. Khusus untuk shalat, umumnya diperlukan waktu hingga 3 bulan agar anak bisa mempraktekkannya dengan benar.

\section{Metode tanya jawab}

Metode tanya jawab sebenarnya adalah metode yang paling umum dalam semua proses pembelajaran, mulai dari tingkat yang paling dasar hingga ke tingkat yang tinggi. Tanya jawab sendiri bersifat spontan, selain dapat mengarahkan perhatian anak didik, juga dapat langsung mengetahui penguasaannya terhadap materi yang diajarkan. Contohnya adalah saat guru di R.A. DDI Addariyah mengajarkan materi ajar Kompetensi Dasar Islam seperti yang berkaitan dengan keimanan, dimana ia mengajarkan bahwa 
rukun iman itu intinya iman kepada Allah, kepada malaikat-malaikat-Nya, Rasul-Rasul-Nya, dan seterusnya. Setelah menyebutkan/menjelaskan hal tersebut, sang guru langsung menanyakan kepada anak didiknya tentang apa inti rukun iman itu. Maka si anak didik secara bersamaan menjawab bahwa inti rukun iman itu ialah iman kepada Allah dan seterusnya.

\section{Metode bermain}

Metode yang jamak dalam pembelajaran di sekolah-sekolah PAUD karena anak-anak yang berada pada kelompok usia dini senang bermain dan sering menghabiskan waktunya dengan permainan. Bermain akan melatih anak untuk menggunakan kemampuan kognitifnya dan mengembangkan kreativitasnya dengan melakukan eksplorasi. Bermain umumnya menggunakan alatalat permainan. Permainan mengajarkan banyak nilai-nilai agama/moral, seperti tolong menolong, bersedia mengalah dan mau menerima kekalahan. Seperti di R.A DDI Addariyah, terdapat sejumlah sarana dan alat-alat bermain baik indoor maupun outdoor yang biasa digunakan oleh anak didik dalam melakukan sebuah aktivitas permainan.

\section{Metode bercerita}

Bercerita adalah salah satu metode yang paling menarik dan umumnya disukai oleh anakanak usia dini. Lewat suatu cerita, guru dapat menyisipkan pesan-pesan yang mengandung nilainilai agama dan moral, seperti kejujuran. Cerita yang disampaikan dapat berupa kisah-kisah nyata ataupun dongeng. Yang penting adalah guru harus mampu mengemas dan menyampaikan cerita tersebut dengan cara yang menarik dan bahasa yang sederhana dan jelas sehingga dapat mengundang perhatian anak dan mudah dicerna. Contohnya adalah cerita tentang Nabi Muhammad SAW dan cerita tentang anak saleh yang biasa dituturkan oleh guru di R.A. DDI Addariyah Palopo. Seringkali guru menggunakan alat bantu seperti boneka dan benda tiruan agar lebih mudah dicerna anak, seperti saat menceritakan dongeng-dongeng dalam dunia margasatwa.

\section{Metode karyawisata}

Metode karyawisata merupakan metode pendidikan dengan mengajak anak didik melakukan observasi langsung ke lapangan. Metode ini menggabungkan pembelajaran dan rekreasi sehingga sifatnya yang menyenangkan akan lebih mudah menarik perhatian anak didik sekaligus membantu perkembangan kognitifnya. Di R.A. DDI Addariyah Palopo, anak didik kadangkadang diajak untuk berkunjung ke sebuah tempat, misalnya ke Masjid Agung, dan dikenalkan fungsi dan bagian-bagiannya, seperti mihrab sebagai tempat imam shalat dan mimbar sebagai tempat khatib berkhutbah. Sehingga anak didik akan memiliki konsep yang jelas, misalnya, tentang masjid dan fungsinya sebagai tempat ibadah ummat Islam.

\section{Sistem Evaluasi}

Dalam penyelenggaraan pendidikan, evaluasi menjadi salah satu komponen yang penting. Hasil evaluasi dapat menjadi bahan yang dapat dimanfaatkan untuk meningkatkan kualitas pendidikan. Evaluasi sendiri dalam konteks pendidikan diartikan sebagai penilaian terhadap tingkat keberhasilan siswa dalam mencapai sebuah tujuan yang telah ditetapkan dalam sebuah program pembelajaran. Evaluasi pendidikan pada PAUD ditujukan untuk mengetahui keefektifan pelaksanaan layanan program stimulasi dan pencapaian hasil-hasilnya oleh setiap anak. Informasi tentang kedua hal tersebut pada gilirannya menjadi masukan untuk meningkatkan kualitas proses dan hasil stimulasi yang dijalankan (Nugraha, 2010:th). Terdapat beberapa prinsipprinsip yang dianut dalam sistem evaluasi PAUD, yaitu:

1. Evaluasi harus berhubungan dengan kegiatan yang telah direncanakan

2. Hasil evaluasi menguntungkan anak

3. Sebaiknya melibatkan kerjasama antara guru, anak, dan orang tua si anak

4. Menggunakan cara yang paling tepat, dianjurkan menggunakan pengamatan langsung

5. Hendaknya dilakukan secara tepat, objektif, dan segera.

Seperti halnya disekolah-sekolah PAUD lainnya, evaluasi terhadap proses kegiatan dan hasil pembelajaran (termasuk penanaman nilai-nilai agama) di R.A. DDI Addariyah Palopo sifatnya kualitatif dan dilakukan pada saat kegiatan/ program sedang dilaksanakan atau setelah selesai dilaksanakan. Setidaknya ada dua jenis evaluasi yang dilakukan di sekolah ini, yaitu:

Evaluasi untuk pengelompokan/kenaikan tingkat kelompok, yaitu dari Kelompok A ke 
Kelompok B. Evaluasi atas dasar tingkat kematangan ini didasarkan pada pada Kriteria Ketuntasan Minimal, yaitu setidaknya mencapai angka 70-80 ke atas yang menjadi standar minimal pencapaian suatu indikator dari setiap bidang pengembangan. Anak didik yang berada pada tingkat kematangan yang sama atau hampir sama ditempatkan pada satu ruangan sehingga stimulus yang diberikan dapat sama pula. Begitu pula anak yang mengalami keterlambatan kematangan juga ditempatkan pada ruang yang sama sehingga stimulusnya juga sama. Untuk itu ada dua rapor, yaitu rapor kelompok A dan rapor Kelompok B.

Evaluasi untuk Kelulusan. Kelulusan diberikan kepada anak yang memiliki rapor kelompok B, telah menyelesaikan seluruh program pembelajaran, dan telah mengikuti ujian RA dan memiliki nilai untuk seluruh bidang pengembangan yang diujikan, minimal nilai masing-masing bidang pengembangan.

Evaluasi terhadap pencapaian perkembangan anak dilakukan dengan cara observasi langsung, unjuk kerja, penugasan dan portofolio (kumpulan hasil karya anak). Hasil evaluasi setiap indikator tahap perkembangan diwujudkan ke dalam empat kategori: Belum Muncul, Mulai Muncul, Berkembang Sesuai Harapan, dan Berkembang Sangat Baik. Catatan-catatan naratif juga digunakan untuk mencatat hal-hal yang sangat menonjol atau lamban serta dorongan-dorongan. Apabila ada catatan-catatan tentang adanya hambatan tertentu, guru akan memberi pengayaan pada anak yang bersangkutan.

\section{Faktor-Faktor Penunjang atau Penghambat}

Upaya penanaman nilai-nilai agama pada anak didik yang menjadi peserta didik di R.A. DDI Addariyah Palopo secara umum berjalan cukup baik. Hasil positifnya dapat dilihat dari munculnya sejumlah kebiasaan-kebiasaan yang baik pada diri siswa-siswanya. Seperti perilaku mereka yang membalas ucapan salam dari peneliti saat berkunjung ke sekolah mereka ataupun mencium tangan guru sebelum pulang ke rumah sebagai bentuk sikap menghormati yang lebih tua. Bahkan, menurut Kepala Sekolahnya, ada murid yang dapat mengingatkan orang tuanya untuk shalat di masjid pada hari Jum'at sesuai yang dipesankan oleh gurunya. Hal-hal yang menunjang kesuksesan upaya penanaman nilai tersebut antara lain adalah:
Semangat dan kerja keras dari para guru di R.A. DDI Addariyah yang tinggi serta tulus bekerja, meskipun menghadapi sejumlah kendala dan keterbatasan, utamanya jumlah upah/honor yang tidak seberapa yang diterima oleh guru-guru yang berstatus sebagai honorer maupun keterbatasan dalam hal fasilitas/alat bantu mengajar. Guru-guru tersebut tetap setia hadir menemani anak-anak didiknya dan memberikan bimbingan-bimbingan yang dibutuhkan oleh anak-anak tersebut. Dengan keterbatasan-keterbatasan yang dihadapi mereka selalu untuk berusaha memberikan hasil yang terbaik dan tetap konsisten mengabdi di R.A. DDI Addariyah Palopo.

Lingkungan sekitar yang relatif aman dan tenang. Lokasi sekolah R.A. DDI Addariyah Palopo jauh dari pasar atau tempat-tempat keramaian. Suasana lingkungan sekolah yang demikian dapat mempermudah proses pendidikan agama pada diri anak didik.

Di samping hal-hal penunjang tersebut, terdapat pula hal-hal yang berpotensi menjadi penghambat, antara lain adalah:

Keterbatasan fasilitas seperti ruang belajar. R.A. DDI Addariyah Palopo hanya menggunakan ruang aula dari Kantor Urusan Agama Kota Palopo. Ruangan tersebut masih terlalu kecil untuk menampung sekitar 100 anak didik, itupun masih harus dibagi menjadi tiga bilik kecil sebagai kelas dan satu ruang kepala sekolah. Ukuran ruangan yang relatif kecil tersebut menyebabkan suasana pembelajaran menjadi gaduh dan bising. Ini berpotensi mengganggu kenyamanan dan konsentrasi belajar anak. Selain itu, juga dapat mengganggu ketertiban di kelas.

R.A. DDI Addariyah Palopo tidak menetapkan buku ajar yang akan menjadi standar bacaan bagi anak-anak. Dalam melakukan proses pendidikan bagi anak-anak didik, guru-guru di sekolah tersebut tidak menggunakan suatu buku/ bacaan yang menjadi standar di sekolah tersebut. Namun hal ini sukar diwujudkan mengingat mayoritas anak didik berasal dari keluarga golongan ekonomi kecil sehingga berpengaruh pada daya beli mereka. Ketersediaan buku ajar yang menjadi acuan sebenarnya dapat memfasilitasi pendidikan di satuan pendidikan PAUD, termasuk pendidikan yang terkait dengan penanaman nilai agama di lembaga terkait. 


\section{PENUTUP}

R.A. DDI Addariyah sebagai salah satu lembaga yang menyediakan layanan PAUD formal di Kota Palopo memiliki andil dalam membentuk calon-calon insan yang berakhlak mulia dan dilandasi oleh ajaran Islam sesuai dengan visi yang ditetapkannya. R.A. DDI Addariyah Palopo yang saat ini memiliki 100 orang anak yang menjadi siswanya belum memiliki kondisi yang memadai untuk menjalankan kegiatan pembelajarannya secara optimal dikarenakan adanya sejumlah kendala/keterbatasan dalam menjalankan proses pendidikannya, baik itu ari segi pendanaan, fasilitas, maupun ruang kelas yang masih berstatus pinjaman.

Penanaman nilai-nilai agama pada R.A. DDI Addariyah Palopo mengacu pada kurikulum yang merupakan paduan dari Kurikulum Kemendikbud dan Kurikulum Kemenag. Nilai-nilai agama dalam kurikulum tersebut mencakup Kompetensi Dasar Islam maupun Kompetensi Akhlak Perilaku dan Sosial Emosional yang intinya adalah aqidah/ keimanan, ibadah, dan akhlak. Penanaman nilainilai agama tersebut dilakukan dengan sejumlah metode, seperti pembiasaan, peneladanan, tanya jawab, demonstrasi, bermain, bercerita, bermain peran, dan karyawisata.Sementara untuk evaluasinya bersifat kualitatif dan naratif yang menunjukkan pencapaian tahapan perkembangan tahapan tertentu, dengan kategori Belum Muncul. Mulai Muncul, Berkembang Sesuai Harapan, dan Berkembang dengan Baik.

Dalam menjalankan kegiatannya di bidang pendidikan, terdapat sejumlah faktor yang dapat menunjang ataupun menghambat kelancaran kegiatan pendidikan, termasuk penanaman nilainilai agama di R.A. DDI Addariyah Palopo.Faktorfaktor penunjang tersebut antara lain semangat dan ketulusan para guru untuk bekerja maksimal meski menghadapi keterbatasan dan lingkungan sekolah yang relatif aman dan tenang. Sedangkan faktorfaktor penghambatnya mencakup keterbatasan fasilitas sekolah dan minimnya bantuan pendanaan dari luar.

\section{UCAPAN TERIMA KASIH}

Penulis menghaturkan terima kasih sebesarbesarnya kepada pihak-pihak yang telah membantu terlaksananya penelitian ini, seperti Ibu Musfirah, S.Ag selaku Kepala R.A DDI Addariyah Palopo beserta guru-guru yang telah membantu dalam proses pengumpulan data, Ibu Nuraeni, SE selaku pembantu lapangan yang ikut mendampingi dan membantu penulis dalam pengumpulan data lapangan, serta Kepala Kantor Kemenag Kota Palopo yang ikut memeberikan saran dalam menetapkan subjek penelitian. Tak lupa penulis haturkan terima kasih untuk pihak redaktur dan editor Jurnal Alqalam yang bersedia membantu perbaikan dan menerbitkan tulisan ini.

\section{DAFTAR PUSTAKA}

Azizah, Wahyu Nafilatul. 2009. Penanaman Nilai Agama Pada Anak di Taman Kanak-Kanak (TK) Muslimat Nahdlatul Ulama (NU) 31 Sumbersari Malang (Skripsi Pada Prodi PAI Jurusan PAI Fakultas Tarbiyah UIN Maulana Malik Ibrahim Malang: Tidak Diterbitkan).

Badan Perencanaan Pemberdayaan Daerah Kota Palopo. Palopo Dalam Angka 2012. Palopo: BPS Kota Palopo.

DEPDIKBUD. 1989. Kamus Besar Bahasa Indonesia. Jakarta: Balai Pustaka.

http://ipisumedang.blogspot.com/2012/01/modelmodel-pembelajaran-paud-2.html

Hakim, Lukman. 2012. "Internalisasi Nilai-Nilai Agama Islam Dalam pembentukan Sikap dan Perilaku Siswa Sekolah Dasar Islam Terpadu Al Muttaqin Kota Tasikmalaya. Jurnal Pendidikan Agama Islam - Ta'lim Vol. 10 No.1 - 2012.

KMA No. 2 Tahun 2010 tentang Rencana Strategis Kementerian Agama 2010-2014.

Moleong, L.J.. 2008. Metode Penelitian Kualitatif. Cet. Ke-25. Bandung: Rosda Karya.

Muhtadi, Ali. 2005. Penanaman nilai-nilai agama Islam dalam pembentukan sikap dan perilaku Siswa Sekolah Dasar Islam Terpadu Luqman al-Hakim, Yogyakarta. Artikel Penelitian, Yogyakarta: Tidak Diterbitkan.

Mulyasa. 2012. Manajemen PAUD. Bandung: Remaja Rosda Karya.

Murdiono, Mukhamad. t.t. "Metode Penanaman Nilai Moral Untuk Anak Usia Dini”. Jurnal Kependidikan Lemlit UNY.

Nugraha, Ali. 2010. Bahan Ajar Evaluasi Pembelajaran Untuk Anak Usia Dini. Bandung: FIP Jurusan Pedagogik PGPAUD UPI.

Pusat Bahasa. 2008. Kamus Bahasa Indonesia, Jakarta: Depdiknas. 
Thalib, Syamsul Bachri. 2010. Psikologi Pendidikan Berbasis Analisis Empiris dan Aplikatif, E. 1., Cet. 1, Jakarta: Kencana.

Yasmin, Martinis, dan Jamilah Sabri Sanan. 2010. Panduan Pendidikan Anak Usia Dini PAUD, Cet. I, Jakarta: GP Press. 